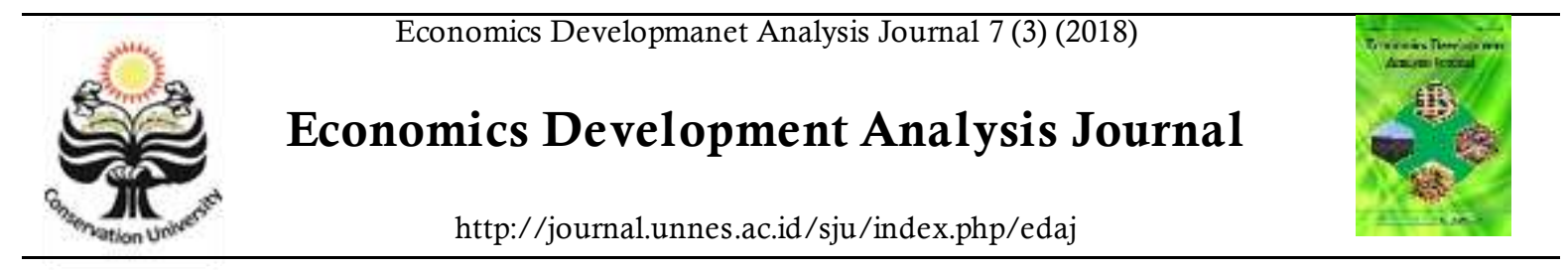

\title{
Strategi Penyerapan Tenaga Kerja Laki-Laki pada Industri Rambut Palsu di Kabupaten Purbalingga
}

\section{Dodi Agustina ${ }^{凶}$}

Jurusan Ekonomi Pembangunan, Fakultas Ekonomi, Universitas Negeri Semarang

\begin{tabular}{l} 
Info Artikel \\
\hline Sejarah Artikel: \\
Diterima April 2018 \\
Disetujui Juni 2018 \\
Dipublikasikan Agustus \\
2018
\end{tabular}

Keywords:

Labor, Gap, Strategy

\begin{abstract}
Abstrak
Penelitian ini menggunakan analisis SWOT, penelitian ini bertujuan untuk mencari tahu apa faktor internal dan eksternal untuk mempromosikan penyerapan tenaga kerja laki-laki di sektor pengolahan rambut palsu. Studi ini juga menganalisis terkait strategi yang dapat dilakukan untuk meningkatkan penyerapan tenaga kerja laki-laki di sektor ini. Sampel dalam penelitian ini berjumlah 97 responden yang merupakan pekerja laki-laki yang saat ini bekerja di bagian pengolahan rambut palsu. Kemudian, responden ahli dalam penelitian ini adalah industri pengolahan rambut palsu dan Departemen Tenaga Kerja Purbalingga. Hasil penelitian menunjukkan bahwa skor Evaluasi Faktor Internal (IFE) adalah 2,3597. Sedangkan skor Evaluasi Faktor Eksternal (EFE) adalah 3,1229. Ini menunjukkan bahwa kondisi internal untuk meningkatkan penyerapan tenaga kerja laki-laki di sektor industri pengolahan rambut palsu masuk ke kategori sedang. Sedangkan kondisi eksternal untuk meningkatkan penyerapan tenaga kerja laki-laki di sektor industri pengolahan rambut palsu masuk ke dalam kategori tinggi. Jadi arah strategis penyerapan tenaga kerja laki-laki di sektor industri pengolahan rambut palsu yang berada di divisi dua. Yaitu dalam pertumbuhan dan fase pembangunan yang dapat ditingkatkan dengan konsentrasi melalui integrasi horizontal
\end{abstract}

\section{Abstract}

This research Using the SWOT analysis, this study seeks to find out what are the strategic factors intermaland external to promote absorption of men in fake hair processing sector. This study also attempts to analyze the strategies that can be done to increase the absorption of men labor in the sector. The sample in this study amounted to 97 respondents who are men workers who are currently worked in the fake hair processing. Then, the expert respondents in this study is the fake hair processing industry and Purbalingga labor depantment. The results showed that the score of the Internal Factor Evaluation (IFE) is 2,3597. While the soreofExternal Factor Evaluation (EFE) is 3,1229. This indicates that the internal conditions for increasing absorption of menlabor in the fake hair processing industry sector in to the medium category. While the external conditionsforincreasing absorption of men labor in the fake hair processing industry sector into the high category. Sothestrategicdirection of the absorption of male labor in the fake hair processing industry sector that are in division two. That is ina growth and a building phase which can be improved by concentration through horizontal integration.

E-mail: edaj@mail.unnes.ac.id 


\section{PENDAHULUAN}

Sampai saat ini telah banyak keberhasilan pembangunan yang telah diraih oleh Kabupaten Purbalingga melalui miteranya dengan industri pengolahan rambut palsu. Dimana melalui kerjasama ini Purbalingga mampu memperluas kesempatan kerja dan meningkatkan pendapatan masyarakat di daerahnya yang sebelumnya tidak sebaik kondisi sekarang. Fakta menunjukkan bahwa tidak kurang dari 52.000 angkatan kerja terserap pada sektor industri ini (Setiansah dan Shinta, 2011:38). Apabila dihitung kasar dengan tingkat upah minimum kabupaten/kota (UMK) Purbalingga yang sebesar Rp.1.522.500,- maka dapat dikatakan bahwa lebih dari Rp.79.170.000.000,- adalah pendapatan yang dapat terserap oleh Kabupaten Purbalingga per bulannya melalui peran tenaga kerja yang bekerja di sektor industri pengolahan rambut tersebut di luar value added ekonomi yang lain.

Lestari (2012:2) menyebutkan bahwa industri pengolahan rambut palsu merupakan sektor industri yang paling dominan di Kabupaten Purbalingga. Dimana dari tujuh jenis industri pengolahan yang ada, 50 persennya adalah industri pengolahan rambut palsu. Selain itu, industri pengolahan rambut palsu juga merupakan sektor industri pengolahan yang menyerap investasi paling tinggi di Kabupaten Purbalingga. Menurut data dari KPMPT (Kantor Penanaman Modal dan Perizinan Terpadu) Kabupaten Purbalingga, menyebutkan bahwa nilai investasi terbesar sampai saat ini masih didominasi oleh sektor industri, terutama industri yang bergerak pada pengolahan rambut palsu. Data dari KPMPT tersebut menunjukan bahwa total investasi yang telah diserap oleh Kabupaten Purbalingga melalui peran sektor industri pengolahan rambut palsu adalah lebih dari Rp.170.240.872.294,00.
Tingginya investasi pada sektor industri pengolahan rambut palsu yang merupakan bagian dari industri pengolahan di Kabupaten Purbalingga sampai saat ini telah memberikan dampak positif terhadap penyerapan tenaga kerja. Dari 322 perusahaan yang ada, perusahaan yang menyerap tenaga kerja dalam jumlah paling besar adalah perusahaan pengolahan rambut (Setiansah dan Shinta, 2011:42). Hal itulah yang membuat penyerapan tenaga kerja di sektor pengolahan menjadi paling tinggi di Kabupaten Purbalingga. Dimana lebih dari $34,06 \%$ tenaga kerja terserap pada sektor tersebut (BPS Purbalingga, 2015). Sedangkan sisanya terserap pada sektor lain seperti pertanian 27,94\%, perdagangan $15,9 \%$, jasa $10,79 \%$ dan sektor lainnya $11,32 \%$.

Selain memiliki tingkat investasi tertinggi, kehadiran industri pengolahan rambut palsu juga telah terbukti mempercepat laju perekonomian di Kabupaten Purbalingga. Bahkan kehadiran industri pengolahan rambut palsu tersebut telah mendorong tingkat pertumbuhan sektor pengolahan menjadi lebih tinggi dari sektor pertanian yang merupakan sektor basis di Kabupaten Purbalingga. Berasarkan data dari Badan Pusat Statistik Kabupaten Purbalingga menyebutkan bahwa tingkat pertumbuhan industri pengolahan sekitar $6 \%$ per tahun sedangkan sektor pertanian hanya berkisar 3\% per tahun. Namun demikian, semakin majunya industri pengolahan rambut palsu di Kabupaten Purbalingga ternyata membuat kesempatan kerja bagi laki-laki di sana menjadi semakin sempit. Hal ini karena penggunaan tenaga kerja laki-laki pada sektor industri pengolahan rambut palsu tidak sebanyak penggunaan tenaga kerja perempuan. Perbandingan penggunaan tenaga kerja laki-laki dan tenaga kerja perempuan pada industri pengolahan rambut palsu dapat dilihat melalui penjabaran tabel berikut: 
Dodi Agustina / Economics Development Analysis Journal 7 (3) (2018)

Tabel 1. Daftar Perusahaan Pengolahan Rambut di Kabupaten Purbalingga

\begin{tabular}{|c|c|c|c|}
\hline \multirow{2}{*}{ No } & \multirow{2}{*}{ Nama Perusahaan } & \multicolumn{2}{|c|}{ Jumlah Tenaga Kerja } \\
\hline & & Laki-Laki & Perempuan \\
\hline 1 & Best Lady & 15 & 63 \\
\hline 2 & Bintang Mas Triyasa & 304 & 702 \\
\hline 3 & Boyang Industrial & 183 & 7135 \\
\hline 4 & Cipta Kreasi Megah & 37 & 110 \\
\hline 5 & Dasindo & 8 & 11 \\
\hline 6 & Elise Eye Lash & 37 & 56 \\
\hline 7 & Fair Lady & 5 & 17 \\
\hline 8 & Midas Indonesia & 52 & 1001 \\
\hline 9 & Milan Indonesia & 62 & 927 \\
\hline 10 & Mitra Jaya Mandiri & 50 & 355 \\
\hline 11 & Hanmi Hair Int & 75 & 813 \\
\hline 12 & Hasta Pusaka Sentosa & 42 & 550 \\
\hline 13 & Hyup Sung & 198 & 1234 \\
\hline 14 & Indokores Sahabat & 423 & 2823 \\
\hline 15 & International Eyelash & 8 & 75 \\
\hline 16 & Interwork Indonesia & 117 & 610 \\
\hline 17 & Kesan Baru Sejahtera & 54 & 126 \\
\hline 18 & Royal Korindah & 325 & 3556 \\
\hline 19 & Sinar Cendana Abadi & 33 & 30 \\
\hline 20 & Sinhan Creatindo & 89 & 270 \\
\hline 21 & SUN Starindo Wirahusada & 17 & 220 \\
\hline 22 & Sung Chang Cab. Bobotsari & 32 & 512 \\
\hline 23 & Sung Chang Indonesia & 275 & 2040 \\
\hline 24 & Sung Shim Int & 88 & 2045 \\
\hline 25 & Tigaputra Abadi Perkasa & 98 & 514 \\
\hline 26 & Morisse & 11 & 19 \\
\hline 27 & Wonjin & 22 & 162 \\
\hline 28 & Yuro Mustika & 64 & 694 \\
\hline
\end{tabular}

Sumber: Dinsosnakertrans Kab. Purbalingga

Selain itu, menjamurnya cabang industri pengolahan rambut palsu yang jumlahnya lebih dari 250 industri rumah tangga ternyata juga menunjukan fakta demikian, dimana 26.949 tenaga kerja perempuan terserap pada cabang industri tersebut sedangkan tenaga kerja laki-laki hanya berjumlah 7.374 orang. Kesenjangan penggunaan tenaga kerja ini semakin diperburuk karena jumlah angkatan kerja laki-laki di Kabupaten Purbalingga lebih mendominasi daripada angkatan kerja perempuannya. Badan Pusat Statistik Kabupaten Purbalingga (2015) menyebutkan jumlah angkatan kerja laki-laki sebesar 268.432 sedangkan angkatan kerja perempuan sebanyak 195.415 orang. 
Melihat angkatan kerja laki-laki yang lebih banyak dari angkatan kerja perempuan ditambah dengan minimnya kesempatan kerja bagi lakilaki untuk bekerja pada industri pengolahan rambut palsu membuat pengangguran laki-laki di Kabupaten Purbalingga selalu lebih tinggi dari pengangguran perempuan setiap tahunnya. Hal ini terjadi karena di satu sisi industri pengolahan rambut menyerap tenaga kerja dalam skala besar namun di sisi lain industri tersebut tidak mempekerjakan tanaga kerja laki-laki sebanyak tenaga kerja perempuan yang digunakan. Berdasarkan publikasi dari BPS Kabupaten Purbalingga (2015) menyebutkan bahwa pengangguran terbuka untuk laki-laki sebanyak 18.316 sedangkan pengangguran terbuka untuk perempuan sebanyak 5.466 orang.

Berdasarkan penjelasan dari awal sebelumnya maka dapat diulas kembali bahwa industri pengolahan rambut palsu merupakan industri yang dapat diandalkan untuk mempercepat laju perekonomian dan mengurangi tingkat pengangguran di Kabupaten

Penelitian ini dilakukan di Kabupaten Purbalingga, tempat dimana terdapat banyak industri pengolahan rambut palsu yang masih minim dalam menggunakan tenaga kerja lakilaki. Selanjutnya, populasi yang digunakan dalam penelitian ini adalah tenaga kerja laki-laki yang saat ini sudah bekerja pada sektor industri pengolahan rambut palsu yaitu berjumlah 2724 tenaga kerja. Teknik pengambilan sampel dalam penelitian ini menggunakan teknik Simple Random Sampling. Nasution (2003:3) mendefinisikan bahwa simple random sampling merupakan proses pengambilan sampel yang dilakukan dengan memberi kesempatan yang sama pada setiap anggota populasi untuk menjadi anggota sampel.

Jumlah sampel yang digunakan dalam penelitian didapat melalui penerapan rumus Slovin. Siahaan dalam (Putri dkk, 2014:4) menjelaskan bahwa pengambilan sampel berdasarkan rumus Slovin dapat dilakukan bila jumlah populasinya sudah diketahui sehingga dapat diketahui dengan pasti jumlah sampel yang terlibat di dalamnya. Jumlah sampel yang
Purbalingga. Namun hal ini masih meninggalkan persoalan dalam penyerapan tenaga kerjanya. Dimana semakin banyak dan semakin majunya industri pengolahan rambut palsu di Kabupaten Purbalingga ternyata semakin membuat kesempatan kerja laki-laki di sana semakin sempit. Oleh karena itu, untuk menyikapi fenomena pembangunan di Kabupaten Purbalingga terkait dengan masalah yang sudah disebutkan, maka penelitian ini berupaya untuk menganalisis strategi penyerapan tenaga kerja laki-laki pada sektor industri pengolahan rambut palsu. Analisis tersebut bertujuan untuk mengetahui apa saja faktor strategis internal dan eksternal yang dapat meningkatkan penyerapan tenaga kerja laki-laki pada industri pengolahan rambut palsu. Selain itu analisis dalam penelitian ini juga bertujuan untuk melihat bagaimana arah strategi yang tepat untuk meningkatkan penyerapan tenaga kerja laki-laki pada sektor tersebut.

\section{METODE PENELITIAN}

digunakan dalam penelitian ini adalah sebagai berikut :

$\mathrm{n}=\frac{N}{1+N(e)^{2}}=\frac{2724}{1+2724(0,10)^{2}}=96,46=97$ sampel

Variabel yang digunakan dalam penelitian ini adalah variabel internal dan variabel eksternal dari tenaga kerja. Variabel internal yang dimaksud terbagi menjadi umur, pendidikan, keterampilan, jumlah tenaga kerja laki-laki, dan produktivitas. Sedangkan variabel eksternalnya terbagi menjadi upah tenaga kerja, ekspansi perusahaan, kebijakan pemerintah dan gender. Metode pengumpulan data yang dilakukan dalam penelitian ini adalah melalui observasi, wawancara, dan kuesioner.

Metode analisis data dalam penelitian ini menggunakan analisis SWOT (Strengths, Weaknesses, Opportunities, dan Threats). Untuk melakukan analisis SWOT ada beberapa tahapan yang harus dilakukan seperti mengidentifikasi faktor-faktor internal dan faktor-faktor eksternal. Faktor-faktor internal yang mempengaruhi penyerapan tenaga kerja laki-laki pada sektor industri pengolahan rambut palsu akan 
diidentifikasi menggunakan matriks Internal Factor Evaluation (IFE). Sedangkan faktorfaktor eksternal yang mempengaruhi penyerapan tenaga kerja laki-laki pada sektor industri pengolahan rambut palsu akan diidentifikasi menggunakan matriks External Factor Evaluation (IFE). Tahap analisis dan penyusunan strategi akan didasarkan pada matriks Internal Eksternal (IE) beserta hasil skor IFE dan EFE yang sudah dianalisis sebelumnya.
Identifikasi faktor-faktor internal dan faktorfaktor eksternal dalam penelitian ini didasarkan atas hasil observasi, wawancara, dan kuesioner penelitian. Sedangkan analisis IFE dan EFE dalam penelitian ini dibantu oleh responden pakar dari pihak industri pengolahan rambut palsu dan pihak Dinas Tenaga Kerja Kabupaten Purbalingga. Secara runtut urutan tahapantahapan analisis yang sudah dijelaskan dapat digambarkan sebagai berikut:

Tabel 2. Tahap-Tahap Analisis SWOT

\begin{tabular}{|l|l|}
\hline $\begin{array}{c}\text { Tahap Masukan } \\
\text { Eksternal (EFE) }\end{array}$ & $\begin{array}{c}\text { Matriks Evaluasi Faktor } \\
\text { Internal (IFE) }\end{array}$ \\
\hline Tahap Analisis & \\
\hline Matriks SWOT & $\begin{array}{c}\text { Matriks Internal } \\
\text { Eksternal (IE) }\end{array}$ \\
\hline
\end{tabular}

Sumber: Iskandarini (2004:1)

\section{HASIL DAN PEMB AHASAN}

Setelah melakukan pengumpulan data dapat diketahui beberapa faktor strategis eksternal dan faktor strategis internal untuk meningkatkan penyerapan tenaga kerja laki-laki pada sektor industri pengolahan rambut palsu. Faktor-faktor strategis eksternal terbagi menjadi peluang dan ancaman. Sedangkan faktor-faktor strategis internal terbagi menjadi kekuatan dan kelemahan. Masing-masing faktor strategis eksternal dan faktor strategis yang dimaksud adalah sebagai berikut:

\section{Peluang}

Industri pengolahan rambut palsu tidak mensyaratkan keterampilan khusus, ada masa training bagi karyawan baru yang diterima di perusahaan pengolahan rambut palsu, masyarakat berkesempatan untuk berkontribusi dalam ekspansi usaha industri pengolahan rambut palsu, belum ada pelatihan dari pemerintah daerah untuk tenaga kerja laki-laki dalam mengolah rambut.
Terdapat 14 dari 16 tahapan proses produksi yang dapat ditempati oleh tenaga kerja laki-laki.

\section{Ancaman}

Dalam perekrutan karyawan baru industri pengolahan rambut palsu lebih mengutamakan pengalaman kerja, perekrutan tenaga kerja baru pada industri pengolahan rambut palsu masih didominasi oleh tenaga kerja perempuan, masih adanya anggapan bahwa yang lebih pantas bekerja pada industri pengolahan rambut palsu adalah tenaga kerja perempuan, banyaknya perusahaan pengolahan rambut palsu yang menggunakan sistem KHL (Karyawan Harian Lepas), masih terdapat perusahaan pengolahan rambut palsu yang mempekerjakan karyawan dibawah umur.

\section{Kekuatan}

Sebagian besar tenaga kerja laki-laki memiliki tingkat pendidikan minimal yang dibutuhkan oleh industri pengolahan rambut palsu, jumlah 
angkatan kerja laki-laki lebih banyak daripada jumlah angkatan kerja perempuan di Kabupaten Purbalingga, tenaga kerja laki-laki merasa nyaman dan tidak merasa malu bekerja di sektor pengolahan rambut palsu, tenaga kerja laki-laki dapat bekerja menggunakan sistem shift work, tingkat produktivitas tenaga kerja laki-laki pada tahap produksi packing, mesin (oven), gosok, obat dan finishing lebih tinggi daripada produktivitas tenaga kerja perempuan.

\section{Kelemahan}

Kebanyakan tenaga kerja laki-laki belum memiliki keterampilan yang dibutuhkan oleh industri pengolahan rambut palsu, minimnya minat tenaga kerja laki-laki untuk ditempatkan pada proses produksi netting dan gunting, tenaga kerja laki-laki sering keluar masuk atau berpindah-pindah dari perusahaan rambut satu ke perusahaan rambut yang lain, mayoritas tenaga kerja laki-laki enggan membawa pekerjaan lembur ke rumah dalam memenuhi target produksi perusahaan, tenaga kerja laki-laki tidak setelaten tenaga kerja perempuan.

Indikator pada faktor-faktor strategis eksternal dan internal di atas merupakan dasar yang digunakan untuk menganalisis Internal Factor Evaluation (IFE) dan External Factor Evaluation (EFE). Melalui bantuan dari responden pakar (pihak industri dan pihak Dinas Tenaga Kerja Kabupaten Purbalingga) dalam memberikan rating dan pembobotan pada setiap indikator di atas, maka dapat dilakukan analisis IFE dan EFE untuk meningkatkan penyerapan tenaga kerja laki-laki pada sektor industri pengolahan rambut palsu yaitu sebagai berikut:

Tabel 3. Skor External Factor Evaluation

\begin{tabular}{|c|c|c|c|c|}
\hline No & $\begin{array}{l}\text { Faktor Strategis Eksternal } \\
\text { Peluang }\end{array}$ & Bobot & Rating & Skor EFE \\
\hline 1 & Industri pengolahan rambut palsu tidak mensyaratkan keterampilan khusus & 0,102 & 3,000 & 0,3070 \\
\hline 2 & $\begin{array}{l}\text { Ada masa training bagi karyawan baru yang diterima di perusahaan } \\
\text { pengolahan rambut palsu }\end{array}$ & 0,091 & 3,667 & 0,3337 \\
\hline 3 & $\begin{array}{l}\text { Masyarakat berkesempatan untuk berkontribusi dalam ekspansi usaha industri } \\
\text { pengolahan rambut palsu }\end{array}$ & 0,139 & 4,000 & 0,5573 \\
\hline 4 & $\begin{array}{l}\text { Belum ada pelatihan dari pemerintah daerah untuk tenaga kerja laki-laki dalam } \\
\text { mengolah rambut }\end{array}$ & 0,121 & 3,667 & 0,4437 \\
\hline 5 & $\begin{array}{l}\text { Terdapat } 14 \text { dari } 16 \text { tahapan proses produksi yang dapat ditempati oleh tenaga } \\
\text { kerja laki-laki }\end{array}$ & 0,089 & 2,667 & 0,2382 \\
\hline \multicolumn{4}{|c|}{ Total Skor Peluang } & 1,8799 \\
\hline No & $\begin{array}{l}\text { Faktor Strategis Eksternal } \\
\text { Ancaman }\end{array}$ & Bobot & Rating & Skor EFE \\
\hline 1 & $\begin{array}{l}\text { Dalam perekrutan karyawan baru industri pengolahan rambut palsu lebih } \\
\text { mengutamakan pengalaman kerja }\end{array}$ & 0,115 & 3,333 & 0,3833 \\
\hline 2 & $\begin{array}{l}\text { Perekrutan tenaga kerja baru pada industri pengolahan rambut palsu masih } \\
\text { didominasi oleh tenaga kerja perempuan }\end{array}$ & 0,111 & 3,333 & 0,3711 \\
\hline 3 & $\begin{array}{l}\text { Masih adanya anggapan bahwa yang lebih pantas bekerja pada industri } \\
\text { pengolahan rambut palsu adalah tenaga kerja perempuan }\end{array}$ & 0,078 & 2,000 & 0,1567 \\
\hline 4 & $\begin{array}{l}\text { Banyaknya perusahaan pengolahan rambut palsu yang menggunakan sistem } \\
\text { Karyawan Harian Lepas }\end{array}$ & 0,082 & 2,333 & 0,1906 \\
\hline 5 & $\begin{array}{l}\text { Masih terdapat perusahaan pengolahan rambut palsu yang mempekerjakan } \\
\text { karyawan dibawah umur }\end{array}$ & 0,071 & 2,000 & 0,1413 \\
\hline \multicolumn{4}{|c|}{ Total Skor Ancaman } & 1,2430 \\
\hline \multicolumn{4}{|c|}{ Total Skor EFE (External Factor Evaluation) } & 3,1229 \\
\hline
\end{tabular}

Sumber: Data diolah

Berdasarkan analisis EFE diatas dapat diketahui bahwa peluang terbesar yang paling berpengaruh terhadap penyerapan tenaga kerja laki-laki pada sektor industri pengolahan rambut palsu adalah "Masyarakat berkesempatan untuk berkontribusi dalam ekspansi usaha industri pengolahan rambut palsu". Sedangkan ancaman terbesar yang paling berpengaruh terhadap 
penyerapa tenaga kerja laki-laki pada sektor industri pengolahan rambut palsu adalah "Dalam perekrutan karyawan baru industri pengolahan rambut palsu lebih mengutamakan pengalaman kerja". Di sisi lain kekuatan yang paling berpengaruh terhadap penyerapa tenaga kerja laki-laki pada sektor industri pengolahan rambut palsu adalah "Tenaga kerja laki-laki dapat bekerja menggunakan sistem shift work".
Sedangkan kelemahan yang paling berpengaruh terhadap penyerapa tenaga kerja laki-laki pada sektor industri pengolahan rambut palsu adalah "Mayoritas tenaga kerja laki-laki enggan membawa pekerjaan lembur ke rumah dalam memenuhi target produksi perusahaan". Secara lebih jelas, hal ini dapat dilihat melalui tabel IFE berikut :

Tabel 4. Skor Internal Factor Evaluation

\begin{tabular}{|c|c|c|c|c|}
\hline \multirow{2}{*}{ No } & Faktor Strategis Internal & \multirow{2}{*}{ Bobot } & \multirow{2}{*}{ Rating } & \multirow{2}{*}{ Skor IFE } \\
\hline & Kekuatan & & & \\
\hline 1 & $\begin{array}{l}\text { Sebagian besar tenaga kerja laki-laki memiliki tingkat pendidikan } \\
\text { minimal yang dibutuhkan oleh industri pengolahan rambut palsu }\end{array}$ & 0,115 & 3,667 & 0,4204 \\
\hline 2 & $\begin{array}{l}\text { Jumlah angkatan kerja laki-laki lebih banyak daripada jumlah } \\
\text { angkatan kerja perempuan di Kabupaten Purbalingga }\end{array}$ & 0,096 & 4,000 & 0,3853 \\
\hline 3 & $\begin{array}{l}\text { Tenaga kerja laki-laki merasa nyaman dan tidak merasa malu bekerja } \\
\text { di sektor pengolahan rambut palsu }\end{array}$ & 0,070 & 3,000 & 0,2110 \\
\hline 4 & Tenaga kerja laki-laki dapat bekerja menggunakan sistem shift work & 0,113 & 4,000 & 0,4507 \\
\hline 5 & $\begin{array}{l}\text { Tingkat produktivitas tenaga kerja laki-laki pada tahap produksi } \\
\text { packing, mesin (oven), gosok, obat dan finishing lebih tinggi daripada } \\
\text { produktivitas tenaga kerja perempuan }\end{array}$ & 0,070 & 3,000 & 0,2110 \\
\hline \multicolumn{2}{|c|}{ Total Skor Kekuatan } & & & 1,6784 \\
\hline No & $\begin{array}{l}\text { Faktor Strategis Internal } \\
\text { Kelemahan }\end{array}$ & Bobot & Rating & Skor IFE \\
\hline 1 & $\begin{array}{l}\text { Kebanyakan tenaga kerja laki-laki belum memiliki keterampilan yang } \\
\text { dibutuhkan oleh industri pengolahan rambut palsu }\end{array}$ & 0,137 & 1,000 & 0,1370 \\
\hline 2 & $\begin{array}{l}\text { Minimnya minat tenaga kerja laki-lakiuntuk ditempatkan pada proses } \\
\text { produksi netting dan gunting }\end{array}$ & 0,072 & 1,667 & 0,1206 \\
\hline 3 & $\begin{array}{l}\text { Tenaga kerja laki-laki sering keluar masuk atau berpindah-pindah dari } \\
\text { perusahaan rambut satu ke perusahaan rambut yang lain }\end{array}$ & 0,109 & 1,333 & 0,1458 \\
\hline 4 & $\begin{array}{l}\text { Mayoritas tenaga kerja laki-laki enggan membawa pekerjaan lembur } \\
\text { ke rumah dalam memenuhi target produksi perusahaan }\end{array}$ & 0,090 & 1,667 & 0,1506 \\
\hline 5 & Tenaga kerja laki-laki tidak setelaten tenaga kerja perempuan & 0,127 & 1,000 & 0,1273 \\
\hline Tota & Skor Kelemahan & & & 0,6812 \\
\hline Tota & Skor IFE (Internal Factor Evaluation) & & & 2,3597 \\
\hline
\end{tabular}

Sumber: Data Diolah

Melalui skor EFE yang sebesar 3,1229 dan IFE sebesar 2,3597 maka dapat diketahui bagaimana arah strategi yang tepat untuk meningkatkan penyerapan tenaga kerja laki-laki pada sektor industri pengolahan rambut palsu.
Untuk mengetahui bagaimana arah strategi tersebut maka diperlukan adanya matriks internal eksternal (IE). Penjelasan lebih lanjut mengenai arah strategi untuk meningkatkan penyerapan tenaga kerja laki-laki pada sektor industri pengolahan rambut palsu adalah sebagai berikut: 
Skor Bobot Total IFE

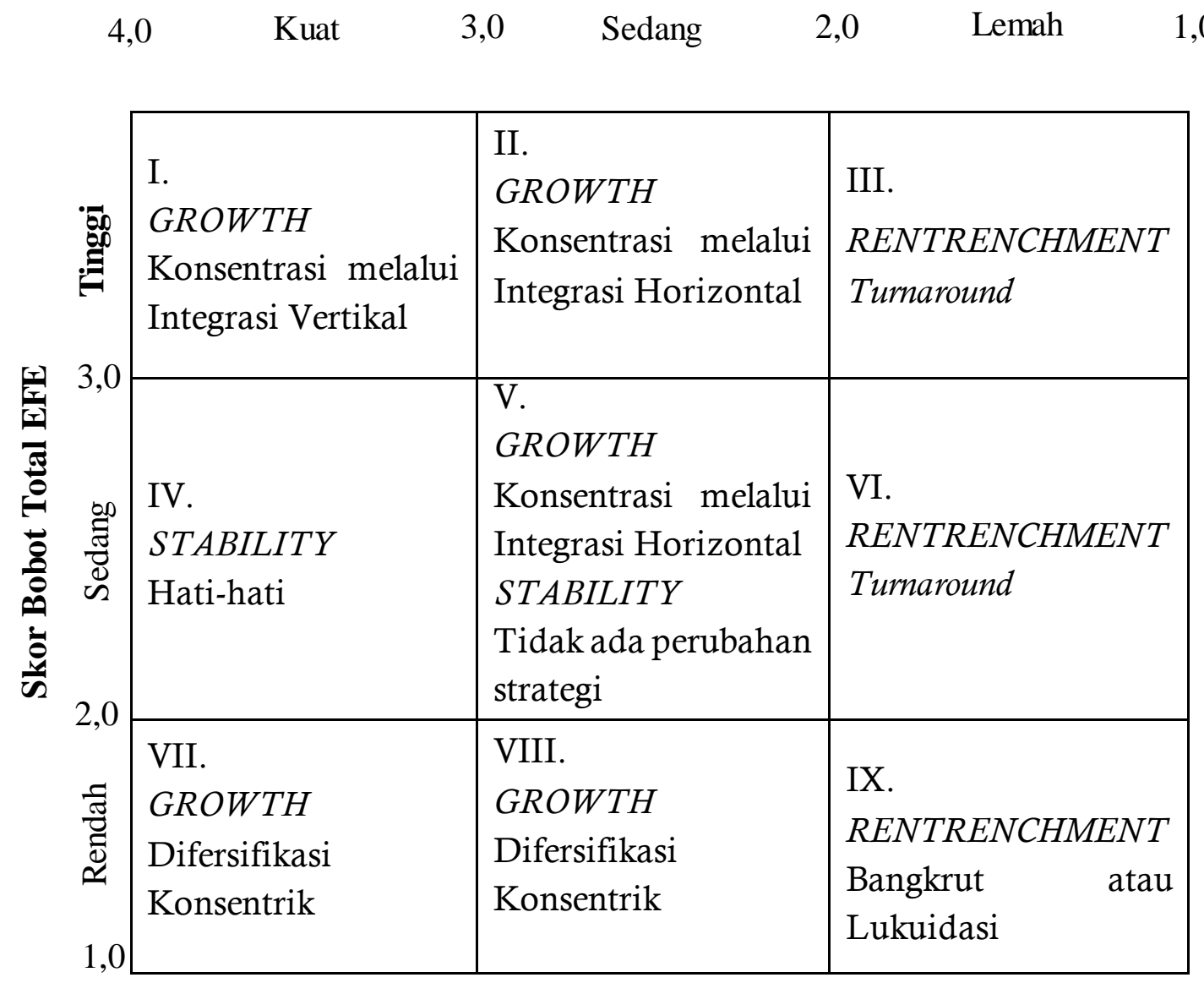

Gambar 1. Matriks Internal Eksternal

Sumber: Data diolah

Nilai IFE yang sebesar 2,3597 tergolong pada kategori sedang. Selanjutnya nilai EFE sebesar 3,1229 masuk dalam kategori tinggi. Sehingga arah strategi penyerapan tenaga kerja laki-laki pada sektor industri pengolahan rambut palsu berada pada fase tumbuh dan membangun yang dapat ditingkatkan dengan konsentrasi melalui integrasi horizontal. Artinya instansi pemerintah yang dalam hal ini adalah dinas tenaga kerja perlu berkoordinasi dengan penyedia lapangan kerja terbesar di Kabupaten Purbalingga sesuai tugas dan kewenangannya dalam merumuskan kebijakan penyerapan tenaga kerja laki-laki pada sektor industri pengolahan rambut palsu.
Mengingat industri pengolahan rambut palsu merupakan sektor yang sangat berpengaruh terhadap kondisi perekonomian di Kabupaten Purbalingga termasuk dalam hal penurunan angka pengangguran, maka dalam hal ini peran dinas tenaga kerja sangat dibutuhkan untuk mempersiapkan kualitas dan kuantitas supply tenaga kerja laki-laki sesuai dengan potensi penyerapan tanaga kerja pada sektor tersebut. Hal ini karena pengangguran laki-laki di daerah tersebut tergolong tinggi. Peran Dinas Tenaga Kerja menjadi penting karena dinas tersebut merupakan dinas yang paling dekat dengan supply tenaga kerja dan merupakan dinas yang memiliki kewenangan 
penuh terhadap peningkatan kualitas tenaga kerja melalui program-program pelatihan di Balai Latihan Kerja.

Di sisi lain industri pengolahan rambut palsu sebagai demand tenaga kerja terbesar di Kabupaten Purbalingga juga memiliki peran strategis dalam penurunan angka pengangguran laki-laki di daerah tersebut apabila supply tenaga kerja laki-laki memiliki kualifikasi yang dibutuhkan oleh industri pengolahan. Sehingga dalam hal ini perlu adanya koordinasi yang harmonis antara dinas tenaga kerja dengan industri pengolahan rambut palsu sesuai dengan perannya masing-masing. Dimana dinas tenaga kerja berperan mempersiapkan kualitas supply tenaga kerja laki-laki sedangkan industri pengolahan rambut berperan sebagai demand tenaga kerja laki-laki.

Untuk memperoleh formulasi strategi kebijakan yang tepat dalam meningkatkan penyerapan tenaga kerja laki-laki pada sektor industri pengolahan rambut palsu di Kabupaten Purbalingga dipergunakan analisis SWOT dengan beberapa alternaif strategi sebagai berikut:

\section{Strategi SO (Strengths Opportunities)}

Mengembangkan kemiteraan (kerja sama) antara pihak industri pengolahan rambut palsu dengan masyarakat melalui regulasi (dasar) yang lebih jelas.

Menempatkan tenaga kerja laki-laki pada bagian proses produksi yang lebih sesuai. Yaitu pada pos-pos produksi tertentu yang memang lebih diprioritaskan untuk ditempati oleh tenaga kerja laki-laki seperti pada bagian produksi mesin (oven), plafon (PL), packing dan finishing.

\section{Strategi ST (Strenghts Threats)}

Pemerintah Daerah setempat khususnya Dinas Tenaga Kerja perlu memonitoring dan membenahi pelaksanaan Pasal 68 Undangundang No. 13 Tahun 2003 tentang "pengusaha dilarang mempekerjakan anak" pada industri pengolahan rambut palsu.

\section{Strategi WO (Weaknesses Opportunities)}

Memberlakukan kontrak perjanjian kerja yang tegas dengan menerapkan penalti terhadap tenaga kerja yang sudah diterima apabila melanggar kontrak perjanjian kerja tersebut. Hal ini bertujuan untuk meminimalisir tingkat turnover tenaga kerja pada industri pengolahan rambut palsu.

Meminimalisir penempatan tenaga kerja laki-laki pada bagian proses produksi yang pengupahannya menggunakan sistem borongan (hitungan hasil) seperti pada bagian produksi netting dan sejenisnya.

\section{Strategi WT (Weaknesses Threats)}

Memberikan pelatihan atau pembekalan keterampilan dasar bagi calon tenaga kerja lakilaki yang akan mendaftarkan diri sebagai tenaga kerja pada industri pengolahan rambut palsu melalui peran BLK (Balai Latihan Kerja) daerah setempat.

Memberikan pemahaman kepada calon tenaga kerja laki-laki bahwa pandangan gender bukanlah penghalang untuk dapat bekerja pada industri pengolahan rambut palsu. Karena pada sektor industri tersebut skill lebih diutamakan dalam perekrutan karyawan baru.

\section{SIMPULAN}

Berdasarkan semua analisis yang telah dilakukan dapat disimpulkan bahwa skor IFE sebesar 2,3597. Skor kekuatan tertinggi yaitu "Tenaga kerja laki-laki dapat bekerja menggunakan sistem shift work". Sedangkan skor kelemahan tertinggi adalah "Mayoritas tenaga kerja laki-laki enggan membawa pekerjaan lembur ke rumah dalam memenuhi target produksi perusahaan". Kemudian, skor EFE sebesar 3,1229. Peluang paling tinggi adalah "Masyarakat berkesempatan untuk berkontribusi dalam ekspansi usaha industri pengolahan rambut palsu". Sedangkan skor ancaman tertinggi adalah "Dalam perekrutan karyawan baru industri pengolahan rambut palsu lebih mengutamakan pengalaman kerja". 
Hasil analisis matriks IE menunjukkan bahwa strategi penyerapan tenaga kerja laki-laki pada sektor industri pengolahan rambut palsu berada pada devisi dua. Sehingga strategi penyerapan tenaga kerja laki-laki pada sektor industri tersebut berada pada fase tumbuh dan membangun yang dapat ditingkatkan dengan konsentrasi melalui integrasi horizontal.

Adapun saran yang dapat diajukan adalah sebagai berikut: satu, Pemerintah daerah setempat khususnya Dinas Tenaga Kerja perlu menyediakan fasilitas pelatihan pengolahan rambut palsu untuk setiap calon tenaga kerja, terutama untuk tenaga kerja laki-laki yang akan mendaftarkan diri sebagai karyawan baru pada sektor industri pengolahan rambut palsu. Hal ini bertujuan agar setiap tenaga kerja dapat terbekali dengan keterampilan dasar yang dibutuhkan oleh sektor tersebut. Kedua, Masyarakat disarankan untuk dapat ikut serta dan berperan aktif dalam ekspansi industri pengolahan rambut palsu. Peran aktif ini dapat dilakukan melalui pembentukan cabang industri kecil, pembentukan koordinator pengepulan (home industry), atau melalui sistem jual putus hasil pengolahan produksi masyarakat dengan pihak industri..

\section{DAFTAR PUSTAKA}

Badan Pusat Statistik Kabupaten Purbalingga. 2015. Produk Domestik Regional Bruto Menurut Lapangan Usaha 2010 - 2014. Lembaran sekretariat daerah. Kabupaten Purbalingga.

Badan Pusat Statistik Kabupaten Purbalingga. 2015. Statistik Daerah Kabupaten Purbalingga 2015. Lembaran sekretariat daerah. Kabupaten Purbalingga.

Daftar UMK untuk 35 Daerah di Provinsi Jawa Tengah. finance.detik.com/ekonomi-bisnis. Diakses, Sabtu 15 April 2017. Pukul 11.25 WIB.

Dinas Sosial, Tenaga Kerja dan Transmigrasi (Dinsosnakertrans) Kabupaten Purbalingga. Daftar Perusahaan Pengolahan Rambut di Kabupaten Purbalingga.

Iskandarini, 2004. Analisis Pemecahan Masalah dan Pengambilan Keputusan. Resume Digitized by USU digital library. Fakultas Pertanian. Universitas Sumatera Utara.
KPMPT Purbalingga. 2015. Daftar Investasi di Kabupaten Purbalingga. http://kpmpt.purbalinggakab.go.id/?page id =533. Diakses, Senin 28 Maret 2016. Pukul $11.30 \mathrm{WIB}$

Lestari, Sri Titi. 2010. Analisis Persebaran Industri Besar di Kabupaten Purbalingga Berbasis Sistem Informasi Geografis (SIG). Jurnal Skripsi. Prodi Geografi Fakultas Ilmu Sosial. Universitas Negeri Semarang.

Nasution, Rozaini. 2003. Teknik Sampling. Modul Statistika. Fakultas Kesehatan Masyarakat. Universitas Sumatera Utara.

Prishardoyo, Bambang. 2008. Analisis Pertumbuhan Ekonomi dan Potensi Ekonomi Terhadap Produk Domestik Regional Bruto (PDRB) Kabupaten Pati Tahun 2002 - 2005. Jurnal Ekonomi dan Kebijakan. Jurusan Ekonomi Pembangunan. Fakultas Ekonomi Unnes. Semaang.

Putri, Nyimas Ekinevita, Retno Astuti, dan Shyntia Atica Putri. 2014. Perencanaan Strategi Pengembangan Restoran Menggunakan Analisis SWOT dan Metode QSPM (Quantitative Strategic Planning Matriks) (Studi Kasus Restoran Big Burger Malang). Jurnal Penelitian TIP Univeritas Brawijaya. Malang.

Setiansah, Mite dan Shinta Prastyanti. 2011. Tidak Ada Pekerjaan untuk Laki-laki di Purbalingga (Menguak Sisi Gelap Pembangunan Masyarakat di Kabupaten Purbalingga). Jurnal Acta diurnA. FISIP. Universitas Jendral Soedirman. Purwokerto. 